\title{
Glycolytic Activities in Size-Fractionated Water Samples: Emphasis on Rhamnosidase, Arabinosidase and Fucosidase Activities
}

\author{
Vanessa Colombo-Corbi*, Maria José Dellamano-Oliveira and Armando Augusto \\ Henriques Vieira \\ Departamento de Botânica; Universidade Federal de São Carlos; Via Washington Luiz, Km 235; 13565-905; São \\ Carlos - SP - Brasil
}

\begin{abstract}
Glycolytic activities of eight enzymes in size-fractionated water samples from a eutrophic tropical reservoir are presented in this study, including enzymes assayed for the first time in a freshwater environment. Among these enzymes, rhamnosidase, arabinosidase and fucosidase presented high activity in the free-living fraction, while glucosidase, mannosidase and galactosidase exhibited high activity in the attached fraction. The low activity registered for rhamnosidase, arabinosidase and fucosidase in the attached fraction seemed contribute to the integrity of the aggregate and based on this fact, a protective role for these structures was proposed. The presented enzyme profiles and the differences in the relative activities probably reflected the organic matter composition as well as the metabolic requirements of the bacterial community, suggesting that bacteria attached to particulate matter had phenotypic traits distinct from those of free-living bacteria.
\end{abstract}

Key words: eutrophic reservoir, extracellular polysaccharides, phytoplanktonic bloom, microbial activity, sizefractionated samples

\section{INTRODUCTION}

Tropical reservoirs are in many cases highly productive aquatic biotopes due to the input of organic materials from land and elevated internal primary production which, in addition to a strong capacity for mineralization, supplies the system continuously with inorganic nutrients (CunhaSantino and Bianchini Jr., 2003; Araújo and Godinho, 2008). Aggregates are considered a very important fraction of the particulate organic matter in these aquatic environments and are in general, heavily colonized by bacteria, becoming a site of intense activity of hydrolytic enzymes. The attached communities can be responsible for up to $75 \%$ of the total hydrolytic activity (Middelboe et al., 1995). The data on extracellular glycolytic activities in size-fractionated water samples are generally related to $\alpha$ - and $\beta$-glucosidases (Smith et al., 1992; Worm et al., 2001; Zoppini et al., 2005), and, in some cases, galactosidases (Zoppini et al., 2005), while several enzymes that hydrolyze other monosaccharides are omitted. Glucose is, in fact, the most important and abundant monosaccharide present in biopolymers from aquatic environments but galactose, mannose,

*Author for correspondence: pvcol@iris.ufscar.br 
xylose, arabinose, fucose and rhamnose are also present in approximately the same equimolar concentrations (Sweet and Perdue, 1982; Gremm and Kaplan, 1997; Repeta et al., 2002; Hayakawa, 2004). The aim of this study was to evaluate the extracellular glycolytic enzymatic activity among different fractions, including some enzymes which had been firstly assayed in aquatic environments.

\section{MATERIAL AND METHODS}

The study was carried out in the Barra Bonita Reservoir, a eutrophic, polymictic reservoir and the sampling site was located at $22^{\circ} 32^{\prime} 34.5^{\prime \prime} \mathrm{S}$, $48^{\circ} 29^{\prime} 26.4^{\prime \prime}$ W. Water samples were collected at several depths $(0,1,3,5,10$ and $18 \mathrm{~m})$ using a Niskin sampler, equally mixed to compose a vertically integrated sample and size-fractionated to obtain the following size fractions: $1.2-10 \mu \mathrm{m}$ (attached bacteria fraction), 0.2-1.2 $\mu \mathrm{m}$ (free living bacteria fraction) and $<0.2 \mu \mathrm{m}$ (free enzymes fraction). Samples fixed with $4 \%$ formaldehyde were stained with 4', 6'-diamidino-2-phenylindole in order to perform the bacterial counting by epifluoescence microscopy (Axioplan, Göttingen, Germany). Hydrolysis of nine fluorogenic substrates was used to assay the activity of enzymes (Table 1).

Table 1 - Enzyes and substrates used to profile the extracellular enzyme activity associated with the bacterioplankton in the Barra Bonita Reservoir.

\begin{tabular}{cc}
\hline MUF-substrate & Enzyme \\
\hline MUF- $\alpha$-L arabinopyranoside & $\alpha$ - arabinosidase \\
MUF - $\beta$-D- fucoside and MUF - $\beta$-L- fucoside & $\beta$-fucosidase \\
MUF- $\alpha$-D- glucoside & $\alpha$-glucosidase \\
MUF- $\beta$-D- glucoside & $\beta$-glucosidase \\
MUF- $\beta$-D- galactoside & $\beta$-galactosidase \\
MUF- $\alpha$-D- mannopyranoside & $\alpha$ - mannosidase \\
MUF- $\beta$-D- mannopyranoside & $\beta$ - mannosidase \\
MUF- $\alpha$-L- rhamnopyranoside & $\alpha$-rhamnosidase \\
\hline
\end{tabular}

All the substrates were purchased from SigmaAldrich (St. Louis, Missouri, USA). The protocol described by Chróst and Krambeck (1986) was properly adjusted by initial kinetics experiments and substrate saturation curves were obtained to establish the optimal MUF-substrate concentration (final concentration of $0.5 \mathrm{mM}$ ). Eight replicates of the samples were mixed with each MUFsubstrate and phosphate buffered solution $(0.1 \mathrm{M}$, $\mathrm{pH} 7$ ) and incubated for 30 minutes at $20^{\circ} \mathrm{C}$. Then, the reactions were interrupted by the addition of $100 \mu \mathrm{L}$ of $5 \mathrm{M} \mathrm{NaOH}$. Substrate hydrolysis was measured in a Jasco FP-6500 spectrofluorometer (Hachioji-shi, Tokyo, Japan) at 365/450 nm, Ex/Em. Calibrations were made with a range of MUF concentrations (1-500 $\mathrm{nM})$ and an autoclaved integrated sample was used as blank.

\section{RESULTS AND DISCUSSION}

Conventionally, bacteria associated to marine snow and particulate matter express more enzymatic activities than the surrounding water mainly during phytoplanktonic blooms (Worm et al., 2001). Taking into account the high extracellular enzymatic activity of associated bacteria when compared to free-living bacteria, it may be assumed that this activity would degrade high molecular organic compounds of the aggregate, which would compromise the maintenance of the structure of the aggregates. However, based on the results, it was observed that arabinosidase, fucosidase and rhamnosidase presented lower activity in the attached form than in the free-living form, and free enzymes revealed an important proportion (38-55\%) compared to the former (Table 2). Glucosidases ( $\alpha$ - and $\beta$-) reached values comparable to other freshwater studies (Worm et al., 2001; Lemarchand et al., 2006). Working with fractionated samples Richardot et al. (1999) registered the highest enzymatic activities for glucosidases ( $\alpha$ - and $\beta$-) in the attached fraction $(2-100 \mu \mathrm{m})$. Since no data was available concerning these enzymes in freshwater aggregates, the low activity of arabinosidase, fucosidase and rhamnosidase in the particles could be related to the process of aggregate construction and persistence. 
Table 2 - Cell-specific enzyme activity for attached and free-living bacteria fractions during the experimental period. Water samples were collected at several depths, equally mixed to compose a vertically integrated sample and size-fractionated to obtain distinct fractions. Mean values are shown $(n=8)$ as a $\%$ of the total activity of the three fractions.

\begin{tabular}{|c|c|c|c|}
\hline & $\begin{array}{c}\text { Attached } \\
\left(\mathrm{nmol} \mathrm{MUF} \mathrm{h}^{-1} \text { cell }^{-1}\right) \\
\end{array}$ & $\begin{array}{c}\text { Free-living } \\
\left(\mathrm{nmol} \mathrm{MUF} \mathrm{h}^{-1} \text { cell }^{-1}\right) \\
\end{array}$ & $\begin{array}{c}\text { Free enzyme } \\
(\%) \\
\end{array}$ \\
\hline$\alpha$-arabinosidase & $1.67 \times 10^{-8}$ & $2.41 \times 10^{-5}$ & 38 \\
\hline$\beta$-fucosidase & $4.57 \times 10^{-9}$ & $3.77 \times 10^{-5}$ & 48 \\
\hline$\alpha$-rhamnosidase & $4.26 \times 10^{-8}$ & $6.89 \times 10^{-5}$ & 55 \\
\hline$\alpha$ - glucosidase & $5.43 \times 10^{-5}$ & $2.30 \times 10^{-8}$ & 12 \\
\hline$\beta$-glucosidase & $2.01 \times 10^{-4}$ & $5.45 \times 10^{-8}$ & 21 \\
\hline$\beta$-galactosidase & $5.93 \times 10^{-5}$ & $2.45 \times 10^{-8}$ & 22 \\
\hline$\alpha$-mannosidase & $6.85 \times 10^{-5}$ & $7.06 \times 10^{-8}$ & 6 \\
\hline$\beta$-mannosidase & $2.05 \times 10^{-4}$ & $2.51 \times 10^{-8}$ & 4 \\
\hline
\end{tabular}

Rhamnose, fucose and arabinose were responsible for $43 \%$ of the total polymeric carbohydrates present in Barra Bonita Reservoir and were correlated with phytoplanktonic blooms, dominated by cyanobacteria, which were probably the main source of extracellular polysaccharide in the system (Dellamano-Oliveira et al., 2007). Some characteristics of these three monosaccharides include the elevated capacity of aggregate formation and refractory traits. The methylated sugars, rhamnose and fucose, are known by their hydrophobic properties due to the methyl group at carbon- 6 as described by Vieira et al. (2008) for the extracellular polysaccharide of Aulacoseira granulate, and this special characteristic increases the reactivity and the capacity of aggregate formation. Giroldo et al. (2003) described a relative increase of the deoxy sugars, fucose and rhamnose during microbial degradation of the polysaccharide released by Thalassiosira $\mathrm{sp}$, revealing a selective degradation that increased hydrophobicity and promoted transparent exopolymer particles (TEP) and aggregate formation. Zhou et al. (1998) correlated the enrichment in fucose and rhamnose with the cohesiveness of natural extracellular polysaccharides and their ability to form watercolumn aggregates. Arabinose-rich bacterial exopolysaccharides have also shown to be responsible for its high capacity for cell aggregation (Panhota et al., 2007).

The relative contribution of some monosaccharides to organic matter has been proposed as an indicator of its degradation stage (Hedges et al., 1994; Biersmith and Benner, 1998) and suggested that the poor glycolytic activity found by rhamnosidase, fucosidase and arabinosidase could reflect the older stage of the organic matter constituting the aggregates with respect to that available in the water and exposed to free-living enzyme activity. The degradation of the aggregates is a multiple-step event and partial degradation actually contributes to the persistence of the aggregates in the water, since the hydrolysis pattern leads to a progressive accumulation of more refractory polysaccharides.

The enzyme profiles here presented, and the differences in the relative activities, reflected the organic matter composition as well as the metabolic requirements of the bacterial community and suggested that bacteria attached to particulate matter had phenotypic traits distinct from those of free-living bacteria. Particulate matter appeared to be a selective habitat relative to the surrounding water, because the expression of some enzymes tended to be more frequent in the attached than in the free-living fraction. However, further studies would be necessary to reveal if the differences observed between the attached and free-living activities of commonly-studied enzymes ( $\alpha$ - and $\beta$-glucosidases) and the supplemental enzymes included in this study were natural physiological responses to the habitat or effective differences between the bacterial communities.

\section{ACKNOWLEDGEMENTS}

Vanessa Colombo-Corbi and Maria José Dellamano-Oliveira were supported by FAPESP (Grants 2002/04117-5, 2002/02517-6 and 2007/58818-8). 


\section{REFERENCES}

Araújo, M.F.F. and Godinho, M.J.L. (2008), Seasonal and spatial distribution of bacterioplankton in a fluvial-lagunar system of a tropical region: density, biomass, cellular volume and morphologic variation. Braz. Arch. Biol. Technol. 51, 203-212

Biersmith, A. and Benner, R. (1998), Carbohydrates in phytoplankton and freshly produced dissolved organic matter. Mar. Chem. 63, 131-144

Chróst, R.J. and Krambeck, H.J. (1986), Fluorescence correction for measurements of enzyme activity in natural waters using methylumbelliferyl-substrates. Arch. Hydrobiol. 106,79-90

Cunha-Santino, M. B. and Bianchini Jr., I. (2003), Oxygen consumption during mineralization of organic compounds in water samples from a small sub-tropical reservoir (Brazil). Braz. Arch. Biol. Technol. 46, 723-729

Dellamano-Oliveira, M.J., Colombo-Corbi, V. andVieira, A.A.H. (2007), Carboidratos dissolvidos do reservatório de Barra Bonita Estado de São Paulo, Brasil) e sua relação com as algas fitoplanctônicas abundantes. Biota Neotrop. 7, 59-66

Giroldo, D., Vieira, A.A.H. and Paulsen, B.S. (2003), Relative increase of deoxy sugars during microbial degradation of an extracellular polysaccharide released by a tropical freshwater Thalassiosira $\mathrm{sp}$ (Bacillariophyceae). J. Phycol. 39,1109-1115

Gremm, T.J. and Kaplan, L.A. (1997), Dissolved carbohydrates in streamwater determined by HPLC and pulsed amperometric detection. Limnol. Oceanogr. 42, 385-393

Hayakawa, K. (2004), Seasonal variations and dynamics of dissolved carbohydrates in lake Biwa. Org. Geochem. 35, 169-179

Hedges, J.I., Cowie, G.L., Richey, J.E., Quay, P.D., Benner, R., Strom, M. and Forsberg, B.R. (1994), Origins and processing of organic matter in the Amazon River as indicated by carbohydrates and amino acids. Limnol. Oceanogr. 39, 743-761.

Lemarchand, L., Jardillier, J., Carrias, J.F., Richardot M., Debroas, D., Sime-Ngando, T. and Amblard, C. (2006), Community composition and activity of prokaryotes associated to detrital particles in two contrasting lake ecosystems. FEMS Microbial. Ecol. 57, 442-451

Middelboe, M., Søndergaard, M., Letarte, Y. and Borch, N.H. (1995), Attached and free-living bacteria: Production and polymer hydrolysis during a diatom bloom. Microb. Ecol. 29, 231-248
Panhota, R.S., Bianchini, I. and Vieira, A.A.H. (2007), Glucose uptake and extracellular polysaccharides (EPS) produced by bacterioplankton from an eutrophic tropical reservoir (Barra Bonita, SPBrazil). Hydrobiologia 583, 223-230

Repeta, D.J., Quana, T.M., Aluwihare, L.I. and Accardia, A. M. (2002), Chemical characterization of high

molecular weight dissolved organic matter in fresh and marine waters. Geochim. Cosmochim. Acta 66, 955962

Richardot, M., Debroas, D., Thouvenot, A., Romagoux, J.C.; Berthon, J.L. and Devaux, J. (1999), Proteolytic and glycolitic activities in size-fractionated surface water samples from an oligotrophic reservoir in relation to plankton communities. Aquat. Sci. 61, 279-292

Smith, D.C., Simon, M., Alldredge, A.L. and Azam, F. (1992), Intense hydrolytic enzyme activity on marine aggregates and implications for rapid particle dissolution. Nature 359, 139-142

Sweet, M.S. and Perdue, E.M. (1982), Concentration and speciation of dissolved sugars in river water. Environ. Sci. Technol. 16, 692-698

Vieira, A.A.H., Ortolano, P.I.C, Giroldo, D., Oliveira, M.J.D., Bittar, T.B., Lombardi, A.T. and Sartori, A.L. (2008), Role of hydrophobic extracellular polysaccharide of Aulacoseira granulata (Bacillariophyceae) on aggregate formation in a turbulent and hypereutrophic reservoir. Limnol. Oceanogr. 53, 1887-1899

Worm, J., Gustavson, K., Garde, K., Borch, N.H. and SØndergaard, M. (2001), Functional similarity of attached and free-living bacteria during freshwater phytoplankton blooms. Aquat. Microb. Ecol. 25,103111

Zhou, J., Mopper, K. and Passow, U. (1998), The role of surface-active carbohydrates in the formation of transparent exopolymer particles by bubble adsorption of seawater. Limnol. Oceanogr. 43, 18601871

Zoppini, A., Puddu, A., Fazi, S., Rosati, M. and Sist, P. (2005), Extracellular enzyme activity and dynamics of bacterial community in mucilaginous aggregates of the northern Adriatic Sea. Sci. Total Environ. 353, $270-286$

Received: August 14, 2009;

Revised: March 25, 2010; Accepted: November 11, 2010 